\title{
Hubungan lama menderita dan derajat luka dengan kecemasan penderita ulkus diabetik
}

\author{
Muhammad Rifai Subri Kano슬 Junaedi Yunding ${ }^{2}$, Muhammad Irwan ${ }^{2}$ \\ ${ }^{1}$ Mahasiswa Fakultas Ilmu Kesehatan Universitas Sulawesi Barat \\ ${ }^{2}$ Fakultas Ilmu Kesehatan Universitas Sulawesi Barat
}

Keywords :

Diabetes mellitus, diabetic foot ulcers, anxiety

\section{Kontak :}

Junaedi Yunding

Email : yundingj@unsulbar.ac.id

Fakultas Ilmu Kesehatan, Universitas

Sulawesi Barat

\section{Vol 2 No 1 September 2019}

\section{https://ojs.unsulbar.ac.id/index.php/j} -healt/article/view/434

\section{(C)2019J-Healt}

ini adalah artikel dengan akses terbuka dibawah licenci CC BY-NC-4.0

https://creativecommons.org/licenses/by-nc/4.0/

\begin{abstract}
Abstrak
Diabetes yang tidak terkontrol dengan baik dapat menimbulkan berbagai komplikasi, salah satunya yaitu ulkus kaki diabetik. Ulkus kaki diabetik adalah kerusakan sebagian atau keseluruhan pada kulit yang dapat meluas ke jaringan bawah kulit, tendon, otot, tulang atau persendian. Intervensi yang dilakukan pada ulkus kaki diabetik adalah perawatan luka, selama proses perawatan luka pasien mengalami kecemasan yang merupakan perasaan tidak nyaman yang belum jelas penyebabnya. Tujuan penelitian untuk mengetahui hubungan lama menderita dan derajat luka dengan kecemasan pada penderita ulkus kaki diabetik di Klinik Ikram WoundCare Center (IWCC). Desain penelitian ini CrossSectional Study dengan pendekatan One Time. Jumlah sampel sebanyak 39 responden diambil dengan cara Non Probability Sampling metode Purposive Sampling, cara pengumpulan data dengan kuesioner dan lembar observasi. Hasil analisis Fisher'sExactTest di peroleh nilai $\rho$ $=0,498$ pada analisis lama menderita dengan kecemasan berarti tidak ada hubungan dan analisis derajat luka dengan kecemasan nilai signifikan diperoleh nilai $\rho=0,163$ disimpulkan bahwa tidak ada hubungan yang bermakna.
\end{abstract}

\section{Abstract}

Diabetes can cause various complications, one of which is diabetic foot ulcer. Diabetic foot ulcers are partial or total damage to the skin that can extend to the tissues under the skin, tendons, muscles, bones or joints. The intervention carried out in diabetic foot ulcers is wound care, during the wound care process the patient experiences anxiety which is an uncomfortable feeling that is not yet clear. The purpose of this study was to determine the relationship between the length of suffering and the degree of injury and anxiety in patients with diabetic foot ulcers at the Ikram WoundCare Center (IWCC) Clinic. The design of this research is CrossSectional Study with One Time approach. The total sample of 39 respondents was taken by means of the Non Probability Sampling Purposive Sampling method, how to collect data by questionnaire and observation sheet. Fisher's Exact Test analysis results obtained $\rho=0.498$ in the analysis of long suffering with anxiety means there is no relationship and analysis of the degree of injury with anxiety significant values obtained $\rho=0.163$ concluded that there was no significant relationship. 


\section{PENDAHULUAN}

Diabetes Melitus merupakan penyakit yang tidak dapat disembuhkan dan memberikan dampak terhadap kualitas sumber daya manusia. (Kusumadewi, 2011). Diabetes biasa dikenal dengan istilah thesilent killer karena penyakit Diabetes dapat menjadi faktor resiko bagi berbagai macam penyakit lain pada organ tubuh dan konsekuensi dari penyakit Diabetes meningkatnya risiko penyakit jantung dan stroke, neuropati atau kerusakan syaraf di kaki, retinopati diabetikum yang merupakan salah satu penyebab utama kebutaan, gagal ginjal bahkan kematian (Kementerian Kesehatan RI, 2014).

World Health Organization (WHO) (2014) menjelaskan DM menjadi penyebab utama dari 1,5 juta kematian dan tahun 2014 Indonesia memiliki sekitar 9,1 juta penyandang DM (WHO, 2014). Tingkat kejadian DM tipe 2 lebih banyak daripada DM tipe 1 maupun DM gestasional di dunia. Prevalensi DM tipe 2 sebesar 30-50\%, sedangkan prevalensi DM gestasional sebesar 10-25\% dan sisanya yaitu DM tipe 1 sebesar $25 \%$ (WHO, 2016).

Ulkus Diabetik salah satu komplikasi yang sering muncul akibat DibetesMilitus terjadi akibats neuropati diabetikum. Ulkus Diabetik juga di sebabkan oleh kalus. Penggunaan alas kaki yang tidak sesuai ukuran dan neuropati motorik akan merubah karakteristik dari postur kaki sehingga membuat kaki menjadi melengkung, ujung kaki menekuk, dan membuat tekanan yang pada tumit dan kaputmetatarsal yang akhirnya akan membuat kulit menjadi tebal (kalus) sehingga menimbulkan ulkus (Fitriah, 2017).

Ulkus diabetikum yang terjadi menyebabkan dampak psikologis yakni cemas dan stres Lestari (2015). Stres yaitu tanggapan tubuh terhadap berbagai tuntutan atau beban atasnya yang bersifat nonspesifik (Yosep \& Sutini 2014).
Penelitian terdahulu menunjukkan hubungan yang signifikan antara lama menderita dengan tingkat kecemasan (Laily,2016). Hasil wawancara yang di lakukan oleh peneliti pada salah satu pasien yakni di dapatkan pada pasien A mengatakan cemas selama menderita Ulkus Diabetik dan pada proses pengobatan pasienmengatakan cemas sudah mulai berkurang melihat kondisi luka kaki sudah mulai ada perubahan selama menjalani perawatan luka.

\section{METODE PENELITIAN}

Penelitian ini merupakan penelitian non eksperimen yaitu descriptiveanalityc, Desain penelitian CrossSectional Study yaitu penelitian dengan mengamati subjek atau subjek diamati dan diobservasi hanya sekali saja pada saat waktu penelitian tersebut, penelitian ini menggunakan observasional dengan pendekatan. Besar sampel pada penelitian ini sebanyak 39 orang.

Penilaian sampel diambil dengan cara Non Probability Sampling metode Purposive Sampling yaitu pengambilan sampel berdasarkan kriteria yang memenuhi syarat dan dijadikan sebagai sampel.

\section{HASIL PENELITIAN}

1. Analisa Univariat

a. Distribusi responden berdasarkan usia dapat dilihat pada tabel berikut :

Tabel 1 Distribusi responden berdasarkan usia pada penderita ulkus kaki Diabetik

\begin{tabular}{cccccc}
\hline Variabel & Mean & Median & $\begin{array}{c}\text { Std. } \\
\text { Deviation }\end{array}$ & Max & Min \\
\hline Usia & 54,38 & 53,00 & 9,773 & 85 & 41 \\
\hline
\end{tabular}

Sumber : Data primer 2019 
Menunjukkan bahwa usia responden didapatkan nilai rata-rata usia 54,38 dengan nilai median 53,00 sedangkan usia minimum responden 41 tahun dan usia maximum responden yang didapatkan 85 tahun.

b. Distribusi responden berdasarkan jenis kelamin dapat dilihat pada tabel berikut :

Tabel 2 Distribusi responden berdasarkan jenis kelamin pada penderita Ulkus kaki Diabetik

\begin{tabular}{ccc}
\hline Jenis_Kelamin & Frekuensi & \% \\
\hline laki-laki & 21 & 53,8 \\
Perempuan & 18 & 46,2 \\
\hline Total & 39 & 100,0 \\
\hline
\end{tabular}

Sumber : Data primer 2019

Menunjukkan bahwa jenis kelamin yang paling banyak adalah laki-laki sebanyak 21 orang $(53,8 \%)$ sedangkan perempuan sebanyak 18 orang $(46,2 \%)$.

c. Distribusi responden berdasarkan derajat luka dapat dilihat pada tabel berikut :

Tabel 3 Distribusi responden berdasarkan derajat luka pada penderita Ulkus Kaki Diabetik

\begin{tabular}{lll}
\hline Derajat Luka & Frekuensi & $\mathbf{\%}$ \\
\hline Derajat II & 26 & 66,7 \\
Derajat III & 5 & 12,8 \\
Derajat IV & 8 & 20,5 \\
\hline \multicolumn{2}{l}{ Total } & 39
\end{tabular}

Sumber : Data primer 2019

Menunjukkan bahwa derajat luka penderita ulkus kaki diabetik yang paling banyak yakni derajat II sebanyak 26 orang $(66,7 \%)$, derajat III tercatat sebanyak 5 orang $(12,8 \%)$ sedangkan derajat IV sebanyak 8 orang $(20,5 \%)$.
2. Analisis Bivariat

Analisis bivariat dalam penelitian ini bertujuan untuk mengetahui hubungan lama menderita dan derajat luka dengan kecemasan pada penderita ulkus kaki diabetik. Penelitian ini sudah di lakukan uji statistik dengan teknik analisis yang digunakan adalah Fisher's Exact Test.

Tabel 4 Analisis Derajat Luka dengan

Kecemasan Pada Penderita Ulkus Kaki

Diabetik

\begin{tabular}{ccccc}
\hline \multirow{2}{*}{$\begin{array}{c}\text { Derajat } \\
\text { Luka }\end{array}$} & $\begin{array}{c}\text { Cemas } \\
\text { Ringan }\end{array}$ & $\begin{array}{c}\text { Cemas } \\
\text { Berat }\end{array}$ & & Total \\
\cline { 2 - 4 } & 20 & 6 & 26 & 0,163 \\
\hline Derajat II & 6 & & \\
$\begin{array}{c}\text { Derajat III } \\
\text { \& IV }\end{array}$ & 7 & 6 & 13 & \\
\hline Total & $69,2 \%$ & $30,8 \%$ & $100,0 \%$ & \\
\hline Sumber : Data primer 2019 & &
\end{tabular}

Menunjukkan dari 39 responden yang diteliti, responden dengan derajat luka II yang mengalami kecemasan dengan kategori cemas ringan didapatkan yakni 20 responden dan kecemasan dengan kategori cemas berat yakni 6 responden, responden dengan derajat luka II sebanyak 26 responden. Selanjutnya responden dengan derajat luka III dan derajat luka IV kategori cemas ringan sebanyak 7 responden dan kategori cemas berat sebanyak 6 responden, jumlah responden dengan kategori derajat luka III dan IV sebanyak 13 responden.

Berdasarkan dari hasil analisa menggunakan uji statistik Fishers's Exact Test dengan nilai signifikan diperoleh $p$ value sebesar 0,163 lebih besar dari nilai $(\alpha)=0.05$ dengan demikian dapat disimpulkan bahwa tidak ada hubungan yang bermakna antara derajat luka dengan kecemasan. 
Tabel 5 Analisi Lama Menderita dengan Kecemasan Pada Penderita Ulkus Kaki Diabetik

\begin{tabular}{|c|c|c|c|c|}
\hline \multirow{2}{*}{$\begin{array}{c}\text { Lama } \\
\text { Menderita }\end{array}$} & \multicolumn{2}{|c|}{ Kecemasan } & \multirow{2}{*}{ Total } & \multirow{2}{*}{$\begin{array}{l}p \text { - } \\
\text { value }\end{array}$} \\
\hline & $\begin{array}{l}\text { Cemas } \\
\text { Ringan }\end{array}$ & $\begin{array}{l}\text { Cemas } \\
\text { Berat }\end{array}$ & & \\
\hline $\begin{array}{ll}< & 10 \\
\text { Tahun } & \end{array}$ & 10 & 6 & 16 & 0,498 \\
\hline $\begin{array}{l}> \\
\text { Tahun }\end{array}$ & 17 & 6 & 23 & \\
\hline Total & $69,2 \%$ & $30,8 \%$ & $100,0 \%$ & \\
\hline
\end{tabular}

Sumber : Data primer 2019

Menunjukkan bahwa distribusi lama menderita dengan kecemasan responden diketahui lama menderita responden yang $<10$ tahun didapatkan kecemasan dengan kategori cemas ringan sebanyak 10 responden dan cemas berat sebanyak 6 responden dengan jumlah responden keseluruhan adalah 16 responden. Selanjutnya lama menderita responden $>10$ tahun mengalami kecemasan dengan kategori cemas ringan sebanyak 17 responden dan cemas berat sebanyak 6 responden. Kecemasan dengan kategori cemas ringan sebanyak 27 setara dengan $69,2 \%$ dan kategori cemas berat sebanyak 12 atau setara dengan $30,8 \%$.

Hubungan lama menderita dengan kecemasan diketahui bahwa tidak ada hubungan yang signifikan dari hasil uji statistik Fisher's Exact Test yang diperoleh p-value sebesar 0,498 yang berarti lebih besar dari nilai $(\alpha)=0.05$. Dengan demikian pada penelitian ini dapat disimpulkan bahwa tidak ada hubungan lama menderita dan derajat luka dengan kecemasan pada penderita ulkus kaki diabetik.

\section{PEMBAHASAN}

Hasil penelitian ini didapatkan tidak ada hubungan lama menderita dengan kecemasan. Hal ini disebabkan karena faktor responden, dimana 39 sampel didapatkan derajat luka yang tidak seragam begitupun juga lama menderita. Responden yang didapatkan oleh peneliti ada 13 responden yang derajat lukanya mencapai hingga derajat IV sedangkan responden yang derajat luka II lebih banyak didapatkan peneliti, begitupun responden yang baru menderita ulkus kaki diabetik dengan lama menderita $<10$ tahun lebih sedikit yakni 16 responden dibandingkan dengan yang lama menderita ulkus kaki diabetik>10 tahun ada 23 responden, berdasarkan hasil penelitian ini yang menunjukkan bahwa responden yang sudah $>10$ tahun sudah tidak lebih cemas karena kondisi yang sudah semakin membaik. Sehingga peneliti mendapatkan mayoritas responden pada penelitian ini adalah cemas ringan.

Berdasarkan hasil analisa Fisher's Exact Test yang menunjukkan bahwa hasil penelitian ini tidak memiliki hubungan lama menderita dengan kecemasan. Hasil diatas menjelaskan bahwa responden yang menderita $<10$ tahun mengalami kecemasan dengan kategori cemas ringan menyatakan bahwa keluarga atau orang terdekat lainnya selalu memberikan dukungan langsung secara fisik maupun psikologis dalam perawatan ulkus. Sedangkan responden yang mengalami cemas berat disebakan karena kurangnya pengetahuan responden pada fase penyembuhan sehingga sering timbul pertanyaan kapan sembuhnya luka yang diderita dalam diri responden yang dinyatakan melalui wawancara langsung oleh peneliti. Lama menderita $>10$ tahun mengalami cemas ringan karena sudah paham dengan fase penyembuhan luka selain itu responden juga sudah lebih bisa menyemangati diri sendiri karena dirinya harus tetap tegar dan tidak boleh meyerah dalam merawat luka, lama menderita $>10$ tahun dengan cemas berat berbeda daripada cemas ringan, cemas berat disebabkan karena sebagian faktor usia yang sudah dikategorikan usia lanjut (60-75 tahun), luka yang susah sembuh dan munculnya luka baru.

Hasil penelitian berdasarkan analisis bivariat dari 39 responden yang diteliti, responden dengan derajat luka II sebanyak 26 responden, diantaranya yang mengalami kecemasan kategori cemas ringan 20 orang, kategori cemas berat sebanyak 6 orang. Derajat luka III dan IV sebanyak 13 responden diantaranya yang mengalami kecemasan dengan kategori 
cemas ringan sebanyak 7 orang dan kategori cemas berat sebanyak 6 orang. Dari hasil data tersebut hasil uji Fisher's Exact Test menunjukkan bahwa penelitian ini didapatkan tidak ada hubungan antara derajat luka dengan kecemasan dengan nilai $p$-value diperoleh 0,163 yang berarti lebih besar dari taraf signifikan $(\alpha)=0.05$.

Berdasarkan hasil penelitian diatas yang dilakukan oleh peneliti didapatkan bahwa tidak ada hubungan derajat luka dengan kecemasan pada penderita ulkus, karena kecemasan yang dialami responden berdasarkan hasil wawancara langsung dengan responden mengatakan bahwa cemas dirasakan bukan disebabkan karena faktor luka, melainkan karena ada beberapa faktor lain yakni diantaranya adalah gangguan tidur, ketegangan otot, keringat dingin dan gangguan pencernaan.

Dalam Penelitian ini telah diusahakan dan dilaksanakan sebaik mungkin sesusai dengan prosedur penelitian. Bagi peneliti selanjutnya diharapkan bisa lebih sempurna dalam memberikan bahasa terhadap responden yang mudah dimengerti dan dipahami.

\section{KESIMPULAN}

Berdasarkan hasil penelitian dari hasil uji Fisher's Exact Test disimpulkan bahwa hubungan lama menderita dan derajat luka dengan kecemasan pada pasien ulkus kaki diabetik di Klinik Ikram Wound Care Center Majene 2019 didapatkan bahwa mayoritas responden mengalami cemas ringan.

Tidak terdapat hubungan yang signifikan antara lama menderita dengan kecemasan dilihat dari nilai $p$-value yang diperoleh sebesar 0,498 begitupun yang dilihat dari hasil analisa derajat luka dengan kecemasan tidak terdapat hubungan yang signifikan.

\section{REFERENSI}

Fitria, E. (2017). Karakteristik Ulkus Diabetikum pada Penderita Diabetes Mellitus Di Rs Dr. Zainal Abidin Dan RSUD Meuraxa banda Aceh. Buletin Penelitian Kesehatan, Vol. 45 No. 3.

Kusumadewi, M. D. (2011). Peran stresor harian, optimisme dan regulasi diri terhadap kualitas hidup individu dengan diabetes melitus tipe 2. Jurnal Psikologi Islam (JPI), 8, 1, 43-62.

Kementrian Kesehatan Republik Indonesia. (2014). Data dan Informasi Profil Kesehatan Indonesia 2016. Diakses tanggal 28 Januari 2019 : http:// www. depkes.go.id/resources/download/pusd atin/lain-lain/Data dan Informasi Kesehatan Profil Kesehatan Indonesia 2014 - smallersize - web.pd

Lestari, M. A. 2013. Gambaran Distribusi Faktor Risiko Pada Penderita Ulkus Diabetika di Klinik Kitamura PKU MuhammadiyahPontianak [serial online]

http://jurnal.untan.ac.id/index.php/jfk/a rticle/viewFile/4142/4170 [19 Februari 2015].

Laily M.N (2016) Faktor yang Berhubungan dengan Tingkat Kecemasan Penderita Diabetes MellitusTipe 2 di Rumah Sakit Nusantara Medika Utama. Diakses tanggal 28 Januari 2019 : http://repository.unej.ac.id/ bitstream/handle/123456789/77360/Nu r\%20Laily\%20Mahmuda.pdf?sequence $=1$

WHO. (2016). Global Report On Diabetes. France: World HealthOrganization; 2016.

Yosep, I., Sutini, T. (2014). Buku Ajar Keperawatan Jiwa (dan Advance mental healyhnursing). Bandung: Refika Aditama. 